\title{
Reliability and Validaty of St George Respiratory Questionnaire (SGRQ) into Indonesian Version
}

\author{
Adnan ${ }^{1}$, Perwitasari DA ${ }^{1}$, Mulyani $\mathbf{U A}^{2}$ \\ ${ }^{1}$ Faculty of Pharmacy, Universitas Ahmad Dahlan, Yogyakarta \\ ${ }^{2}$ National Health Institute, Jakarta, Indonesia
}

\begin{tabular}{l} 
Article Info \\
\hline Article history: \\
Received Jul 12, 2014 \\
Revised Aug 20, 2014 \\
Accepted Aug 26, 2014
\end{tabular}

Keyword:

Indonesia

SGRQ

Tuberculosis

Validation

\begin{abstract}
Tuberculosis (TB) is one of the diseases as the highest contributor to the disease burden in Indonesia. Tuberculosis can affect the patients' quality of life, such as psychological, physical, and social functioning. St. George's Respiratory Questionnaire (SGRQ) is a special instrument which was widely used to measure the patients' quality of life with respiratory disease. The objective of this study was to understand the reliability and to validate the Indonesian version of the SGRQ as instrument to collect data. A descriptive cross section design with 61 subjects was conducted at the Pulmonary Clinics and Primary Health Centers in the region of Yogyakarta within 3 months. The validation process included the known group validity, convergent and discriminant validity and factor analysis. All of the domains met the reliability criteria (Cronbach- $\alpha$ was $\geq 0.7$ ). There were 14 items question numbers which did not meet the criteria for convergent validity and 9 items which did not meet the criteria for discriminant validity. Known group validity analysis on gender showed that of the three domains of SGRQ, the activity domain gave statistically significant result. The factor analysis showed the result of Kaiser Meyer Olkin analysis (KMO) was less than 0.5. With a few modifications, the Indonesian version of SGRQ is valid and reliable for measuring quality of life in tuberculosis patients.
\end{abstract}

Copyright (c) 2014 Institute of Advanced Engineering and Science. All rights reserved.

\section{Corresponding Author:}

Perwitasari DA,

Faculty of Pharmacy,

University of Ahmad Dahlan Yogyakarta,

Jl Prof Dr Soepomo Janturan Yogyakarta, Kampus III, UAD.

Email: diahperwitasari2003@yahoo.com

\section{INTRODUCTION}

Tuberculosis (TB) is a disease that affects many people in the world. In 1992, the World Health Organization (WHO) declared TB as a "Global Emergency" [1]. Tuberculosis can affect the patient's quality of life, such as psychological health, physical functioning, and social role [2]. Saint George's Respiratory Questionnaire (SGRQ) is a special instrument which was widely used to measure the quality of life of patients, especially in respiratory disease [3].

In some countries, such as China, Morocco, India, have done translation and validation of the SGRQ to measure quality of life in patients with respiratory diseases such as asthma, chronic obstructive pulmonary disease (COPD) and bronchiectasis, and the result is the SGRQ valid and reliable for measuring the quality of life of patients with respiratory disease [4]-[6]. In Indonesia, the Indonesian version of the SGRQ was created to be used as instruments to measure quality of life of patients with TB. TB is a respiratory disease that can affect the patient's quality of life.

Assesment of validation and reliability SGRQ Indonesian version has not been done, therefore, with the differences in ethnic background, culture, and language, it is very important to do assay of validation and 
reliability SGRQ in Indonesian version. This study was aimed to test the validity and reliability of the Indonesian version of the SGRQ instrument data collectors to ensure that research data produced valid and reliable.

\section{RESEARCH METHOD}

Design

The descriptive cross section design was conducted at the Pulmonary Clinics and Primary Health Centers in the region of Yogyakarta. Data collection was done by direct observation using a questionnaire conducted at any given time.

Subjects

Subjects in this study were patients who were diagnosed with pulmonary TB who take the medication at Pulmonary Clinics and Primary Health Centers in Yogyakarta. The inclusion criteria were newly diagnosed pulmonary TB patients, aged more than 17 years, willing to engage in research, and not illiterate.

\section{Data Collection}

We collected age, gender, education, and patients' quality of life as demographics data. The SGRQ instrument was given to the respondent to be filled. The data was collected between November 2012 to January 2013.

\section{Statistical analysis}

The demographic data was presented as descriptive data with means and standard deviations (SDs). The convergent and discriminant validities were assessed by Pearson correlation test. The convergent validity was revealed if the item domain correlation was $\geq 0.40$, while the requirements for discriminant validity were satisfied if the value of correlation coefficients between the item and its own domain was higher than other domains. The known-group validity was evaluated based on different diagnoses using t-test.

\section{RESULTS AND ANALYSIS}

The Indonesian version of the SGRQ validation is the first study about specific questionnaire validity in TB patients conducted in Indonesia. SGRQ original version was developed in 1990 by Jones et al [7] to measure the impact of the disease on the health and well-being in patients with chronic obstructive pulmonary disease (COPD).

Table I presents the subjects' characteristics in this study. The distribution of pulmonary TB patients based on the gender classification in this study was 32 males $(52.5 \%)$ and 29 women $(47.5 \%)$. The other study of Li et al [8], recruited 206 men (63.8\%) and 117 women (36.2\%). However, Pasipanodya et al [9] obtained the ratio between men and women 69\%: 31\%. The previous study conducted by in Yogyakarta in 2011 [10], showed the ration of male-female was 56\%: 44\%. There was one different from Pakistan study conducted by Codlin et al [11] which recruited more women as TB sufferer than men.

According to the WHO, the prevalence of pulmonary tuberculosis in men 2,3 times more than women, especially in developing countries, because the men do more social activities. Comparison of the prevalence of pulmonary tuberculosis among men and women alike until the age of adolescence, but after adolescence, prevalence in male is higher than female. This is presumably due to the adolescent only contacts with small environments but adult males have contacts with the larger environment outside the home than women in addition to biological factors, including sociocultural stigma of TB [12].

Another factor that could support why men have a higher TB prevalence than women is smoking habit. Research conducted by Wang and Shen [13], recommended smoking cessation interventions for TB infection control in China.

From the data of education, it was indicated that the highest level of education of TB patients was bachelor (11.5\%). In a previous study in Yogyakarta by Ratnasari [14] showed that most respondents (46\%) had a relatively high level of education higher education. In this study, the level of education of respondents in the high category, where the level of education high school to college was huge amount that was 39 (64\%). In this case, the assumption that the level of education affects the incidence of TB is not applicable. However, the results of this study show that the more educated people are not related with having better awareness about health. 
Table 1. Subjects Characteristics

\begin{tabular}{lcc}
\hline & $\mathbf{n}$ & $\mathbf{\%}$ \\
\hline Age, years (n=61) & $39.2(16.3)$ & \\
Mean (SD) & $18-79$ & \\
Range & & \\
Sex (61) & 32 & 52.5 \\
$\quad$ Male & 29 & 47.5 \\
Female & 7 & \\
Education (n=61) & 15 & 11.4 \\
Primary school & 28 & 45.6 \\
Junior High school & 4 & 6.6 \\
Senior High school & 7 & 11.5 \\
Junior college & & \\
Bachelor &
\end{tabular}

Table 2 shows that the average score of symptom domains was $56,64 \pm 22,42$, activity domains was $52.46 \pm 26.02$ and impact domain was 46,78 $\pm 19,54$. The percentage of the value of floor and ceiling effects for all three domains were quite low, all were less than $20 \%$. The third floor of the range of domain values were ranged from $1.6 \%-6.6 \%$ and the ceiling value range were in the range of $1.6-4.9 \%$, so in this study, we did not find floor and ceiling effects. Table II also describes the internal consistency of the SGRQ. As shown in Table 2, the value of Cronbach's alpha coefficient for all three domains above 0.70 . The floor value for all domains (symptoms, activity, and impact) were $1.6 \%, 6.6 \%$, and $1.6 \%$, respectively. Sequentially to ceiling value for all domains (symptoms, activity, and impact) were $4.9 \%, 4.9 \%$, and $1.6 \%$. This result is the same as that expressed by Pasipanodya et al [9] in their study that there were no floor and ceiling effects for all three domains of the SGRQ. These results provide additional fact that the SGRQ is an appropriate instrument to be used to measure quality of life in patients with TB.

Table 2. Mean, SD, Floor and Ceiling effect, and Internal Consistency

\begin{tabular}{cccccc}
\hline Domain & Mean & SD & Floor (\%) & Ceiling (\%) & $\begin{array}{c}\text { Cronbach's } \boldsymbol{\alpha} \\
\text { coefficient }\end{array}$ \\
\hline Symptom & 56,64 & 22,42 & 1.6 & 4.9 & 0.752 \\
Activity & 52,46 & 26,02 & 6.6 & 4.9 & 0.877 \\
Impact & 46,78 & 19,54 & 1.6 & 1.6 & 0.839 \\
\hline
\end{tabular}

Research in Morocco by Rhazi et al [5], who performed in asthma and COPD patients, reported that the Cronbach alpha values of all three domains of SGRQ were greater than 0.70 . Another study by Xu et al [4], in China the validation SGRQ in COPD patients, reported that the Cronbach alpha value generated was similar to our study. These results can be used as evidence, that the SGRQ is a reliable instrument or as a reliable tool for measuring quality of life in patients with TB.

Table 3 shows that there was no significant difference in the two domains of SGRQ (symptoms, and impact) based on gender differences in men and women $(\mathrm{P}>0: 05)$, except for activity domain $(\mathrm{P}<0,05)$. This fact explained that the opposite gender will give different results on the activity domain.

Table 3. Known group validity

\begin{tabular}{ccccc}
\hline \multirow{2}{*}{ Gender } & $\mathrm{N}$ & Symptoms & Activity & Impact \\
& & Mean \pm SD & Mean \pm SD & Mean \pm SD \\
\hline Female & 29 & $60,7 \pm 21,6$ & $53,7 \pm 30,6$ & $49,7 \pm 20,1$ \\
Male & 32 & $52,9 \pm 22,8$ & $51,3 \pm 21,5$ & $44,2 \pm 18,9$ \\
$P$ value & - & 0,85 & 0,04 & 0,71 \\
\hline
\end{tabular}

Table 4 presents the results of convergent validity and discriminant validity analysis. The questions numbers 1-8 which were the domain of symptoms, met the criteria of convergent and discriminant validity. The questions in activity domain met the criteria for convergent validity, except for the items number 11 and 13. The impact domain consisting of 26 items of questions met the criteria of convergent validity, except for the item in question number $25,30,31,32,33,34,35,45,46,47,48$, and 49. Overall, Table 4 describes that, in general all items meet the discriminant validity questions, unless the question number 11 (activity domain), and the numbers 23, 30, 32, 45, 46, 47, 48, and 49 (impact domain) which do not meet the criteria for discriminant validity. 
Table 4. Convergent and discriminant validity

\begin{tabular}{|c|c|c|c|}
\hline \multirow{2}{*}{ Question } & \multicolumn{3}{|c|}{ Domain } \\
\hline & Symptoms & Activity & Impact \\
\hline 1 & .603 & .261 & .369 \\
\hline 2 & .515 & .058 & .195 \\
\hline 3 & .506 & .238 & .344 \\
\hline 4 & .721 & .220 & .436 \\
\hline 5 & .718 & .109 & .446 \\
\hline 6 & .698 & -.025 & .286 \\
\hline 7 & .518 & .137 & .213 \\
\hline 8 & .549 & -.111 & .194 \\
\hline 11 & $.420 *$ & .285 & .390 \\
\hline 12 & .450 & .551 & .460 \\
\hline 13 & .307 & .364 & .364 \\
\hline 14 & .173 & .602 & .441 \\
\hline 15 & -.089 & .700 & .264 \\
\hline 16 & -.122 & .558 & .120 \\
\hline 17 & -.219 & .605 & .121 \\
\hline 36 & .351 & .555 & .428 \\
\hline 37 & .277 & .523 & .399 \\
\hline 38 & .236 & .694 & .521 \\
\hline 39 & .010 & .632 & .449 \\
\hline 40 & -.078 & .752 & .386 \\
\hline 41 & -.122 & .660 & .264 \\
\hline 42 & -.028 & .780 & .415 \\
\hline 43 & -.003 & .707 & .362 \\
\hline 44 & -.015 & .734 & .407 \\
\hline 9 & .361 & .243 & .577 \\
\hline 10 & .313 & .241 & .575 \\
\hline 18 & .413 & .056 & .493 \\
\hline 19 & .363 & .273 & .602 \\
\hline 20 & .329 & .328 & .637 \\
\hline 21 & .441 & .435 & .527 \\
\hline 22 & .244 & .285 & .581 \\
\hline 23 & .071 & .512 & .468 \\
\hline 24 & .226 & .057 & .418 \\
\hline 25 & .363 & .038 & .376 \\
\hline 26 & .207 & .185 & .507 \\
\hline 27 & .411 & .170 & .559 \\
\hline 28 & .413 & .230 & .476 \\
\hline 29 & .231 & .287 & .546 \\
\hline 30 & .054 & $.373 *$ & .245 \\
\hline 31 & .177 & .222 & .361 \\
\hline 32 & $.330 *$ & .115 & .321 \\
\hline 33 & .213 & .185 & .357 \\
\hline 34 & .211 & .008 & .327 \\
\hline 35 & .043 & .200 & .326 \\
\hline 45 & -.091 & $.548 *$ & .288 \\
\hline 46 & .057 & $.408 *$ & .317 \\
\hline 47 & .103 & $.503^{*}$ & .346 \\
\hline 48 & .164 & $.563^{*}$ & .383 \\
\hline 49 & .165 & $.344 *$ & .332 \\
\hline 50 & .243 & .504 & .564 \\
\hline Symptom & 1 & .183 & .527 \\
\hline Activity & .183 & 1 & .617 \\
\hline Impact & .527 & .617 & 1 \\
\hline
\end{tabular}

- The bold numbers showed that the coefficient correlation between the items and its own domain were $\leq 0.40$.

- The number with* showed that the coefficient correlation between the item and other domain was higher than the coefficient correlation of the item and its own domain. All the values in the boxes were significantly correlated.

Table 4 shows the discriminant and convergent validity of all questions on SGRQ. A total of $72 \%$ (36 of 50 item questionnaire) gave significant correlation. It is the same as that conveyed in research in India by Aggarwal et al [6], that the results for all domains of the SGRQ provided a good correlation, except in the impact domain. According to Aggarwal et al [6], the low correlation could be seen from the response of the respondents answer questions that the answer was "yes and no". It means that all of the items met the criteria of convergent validity and discriminant validity, except for the impact domain. There were some questions that did not meet the item convergent and discriminant validity. This study showed that, the items that did not 
meet the question of convergent validity had low correlation with the domain itself. This is as shown in item question number 11 and 13 (domain activity) and item question number 25, 30, 31, 32, 33, 34, 35, 45, 46, 47, 48 , and 49 (domain effect) had athe value correlation coefficient of less than 0.40 , so they did not meet the criteria for convergent validity. This happens probably because the respondents had problems in understanding the intent of the question, and the respondent had difficulty to translate what they feel. Thus, improvements should be made to the questions that will be more easily understood by respondents.

Based on the criteria of discriminant validity, the question number 11 (domain activity) did not meet the criteria because it should be correlated with the activity domain has tended to correlate more strongly to symptom domains. These results show that respondents interpreted the activity of sitting or lying down could cause pain was a symptom rather than an activity. So the question item numbers $23,30,32,45,46,47,48$, and 49 (domain effect) were more correlated with the impact domain, infact, more precisely correlated with the activity domain. This happens could be caused by the difficulty of respondent in interpreting the intent of the question. The question numbers 45-49 which were the contents of any problems in the chest, such as could not exercise or lie down, cannot go on vacation, cannot go out of the house, cannot do your homework and cannot step away from the bed or seats which were all impacts of the problems in the chest, more likely to be perceived as an activity rather than an impact by respondent. It is therefore necessary to repairs the questions so that the respondents would be easier to understand the question.

\section{CONCLUSION}

According to the analysis result, overall, the Indonesian version of SGRQ can be used a valid and reliable instrument to measure the quality of life of TB patients. However, some modifications need to be done on the question to make it more easily understood by respondents.

\section{REFERENCES}

[1] Anonim, "Tuberkulosis, Pedoman dan Penatalaksanaan di Indonesia, Perhimpunan Dokter Paru Indonesia", pp 2, 2002.

[2] Duhria, M. Sharma, N., Ingle, G.K., "Impact of Tubercolusis on the Quality of Life", Indian J Community Med, vol/issue: 33(1), pp. 58-59, 2008.

[3] Aggarwal, A.N., "Health Related Quality of Life: A Neglected aspect of pulmonary Tubercolusis", Lung India, vol/issue: 27(1), pp. 1-3, 2010.

[4] Xu, W., Collet, J.P., Shapiro, S., Lin, Y., Yang, T., Wang, C., et al., "Validation and clinical interpretation of the St George's Respiratory Questionnaire among COPD patients, China”, Int. J. Tuberc. Lung. Dis, vol/issue: 13(2), pp. 181-189, 2009.

[5] Rhazi, K. E., Nejjari. C., Benjelloun. M. C., et al., "Validation of the St George's Respiratory Questionnaire in patients with COPD or asthma in Morocco", Int. J. Tuberc. Lung. Dis, vol/issue: 10(11), pp. 1273-1278, 2006.

[6] Aggarwal, A. N, Gupta. D, Kumar. T., Singh. N., Jindal. S.K., "Validation of Hindi Translation of St. George's Respiratory Questionnaire in Indian Patients with Chronic Obstructive Pulmonary Disease", Indian J Chest Dis Allied Sci, vol. 49, pp. 87-92, 2007.

[7] Jones, P. W., Quirk, F. H., Baveystock, C. M., Littlejohns, P., "A self-complete measure of health status for chronic airflow limitation: the St. Georges's Respiratory Questionnaire”, Am Rev Respir Dis, vol. 145, pp. 1321-1327, 1992.

[8] Li, X., Jiang, S., Li, X., Mei. J., Zhong, Q., Xu, W., et al., "Predictors on Delay of Initial Health-Seeking in New Pulmonary Tuberculosis Cases among Migrants Population in East China”, PLoS ONE, vol/issue: 7(2), pp. 31995, 2012.

[9] Pasipanodya, J.G., Miller, T. L., Vecino, M., Munguia, G., Bae, S., Drewyer, G., et al., "Using the St. George Respiratory Questionnaire To Ascertain Health Quality in Persons With Treated Pulmonary Tuberculosis", Chest, vol/issue: 132(5), pp. 1591-1598, 2007.

[10] Ahmad, R. A., Mahendradhata, Y., Utarini, A., Vlas. S. J., "Diagnostic delay amongst tuberculosis patients in Jogjakarta Province, Indonesia is related to the quality of services in DOTS facilities", Trop Med Int Health, vol/issue: 16(4), pp. 412-423, 2011.

[11] Codlin, A.J., Khowaja, S., Chen. Z., Rahbar, M.H., Qadeer. E., Ara. I., et al., "Short Report : Gender Differences in Tuberculosis Notification in Pakistan", The Am.J.Trop.Med.Hyg, vol/issue: 85(3), pp. 514-517, 2011.

[12] Nofizar, D., Nawas, A., Burhan. E., "Identifikasi Faktor Risiko Tirberkulosis Multidrug Resistant (TB-MDR)", Maj.Kedok.Indon, vol/issue: 60(12), pp. 537-545, 2010.

[13] Wang. J., Shen. H., "Review of cigarette smoking and tuberculosis in China: intervention is needed for smoking cessation among tuberculosis patients", BMC Public Health, vol/issue: 12(9), pp. 292, 2009.

[14] Ratnasari, N. Y., "Hubungan Dukungan Sosial Dengan Kualitas Hidup Pada Penderita Tuberkulosis Paru (TB Paru) Di Balai Pengobatan Penyakit Paru (BP4) Yogyakarta Unit Minggiran”, Jurnal Tuberkulosis Indonesia, vol. 8, pp. 7-11, 2012. 


\section{BIOGRAPHIES OF AUTHORS}

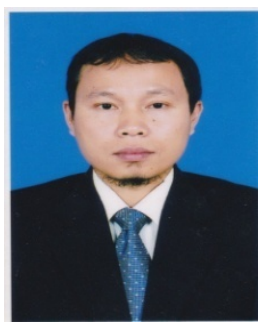

Adnan, M.Sc., Apt graduated from Faculty of Pharmacy, University of Ahmad Dahlan Yogyakarta. Currently, He is working as lecturer and researcher in Faculty of Pharmacy, University of Ahmad Dahlan Yogyakarta.

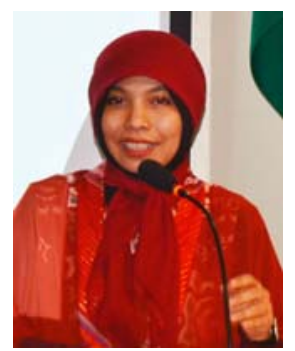

Dr. Dyah A Perwitasari was graduated from Leiden University Medical Center, The Netherlands in the field of Clinical Pharmacy and Toxicology. The thesis was related with the cancer patients' quality of life and pharmacogenetic. Currently, she is working as lecturer and researcher in Faculty of Pharmacy, University of Ahmad Dahlan Yogyakarta.

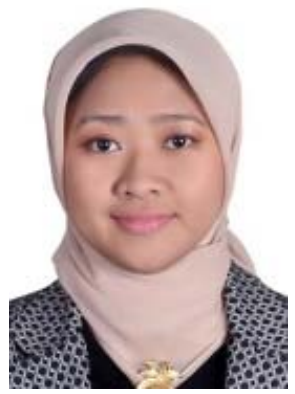

Ully Adhi Mulyani, M.Sc., Apt is researcher from National Health Institute, Jakarta, Indonesia. 